\title{
Seasonal Variability of Snow Density in the Spanish Pyrenees
}

\author{
Eduardo Lastrada ${ }^{1, * \mathbb{D}}$, Guillermo $\operatorname{Cobos}^{1} \mathbb{D}$, Julio Garzón-Roca ${ }^{2} \mathbb{D}$ and F. Javier Torrijo ${ }^{1,3} \mathbb{D}$ \\ 1 Department of Geological and Geotechnical Engineering, Universitat Politècnica de València, \\ 46014 Valencia, Spain; gcobosc@trr.upv.es (G.C.); fratorec@trr.upv.es (F.J.T.) \\ 2 Independent Researcher, 46014 Valencia, Spain; ing.jgarzon@gmail.com \\ 3 Research Centre PEGASO, Universitat Politècnica de València, 46014 Valencia, Spain \\ * Correspondence: edlasmar@aaa.upv.es
}

Citation: Lastrada, E.; Cobos, G.; Garzón-Roca, J.; Torrijo, F.J. Seasonal Variability of Snow Density in the Spanish Pyrenees. Water 2021, 13, 1598. https://doi.org/10.3390/ w13111598

Academic Editor: Maria Mimikou

Received: 1 April 2021

Accepted: 3 June 2021

Published: 7 June 2021

Publisher's Note: MDPI stays neutral with regard to jurisdictional claims in published maps and institutional affiliations.

Copyright: (c) 2021 by the authors. Licensee MDPI, Basel, Switzerland. This article is an open access article distributed under the terms and conditions of the Creative Commons Attribution (CC BY) license (https:// creativecommons.org/licenses/by/ $4.0 /)$.

\begin{abstract}
Spanish latitudes and meteorological conditions cause the snow phenomena to mainly take place in mountainous areas, playing a key role in water resource management, with the Pyrenees as one of the most important and best monitored areas. Based on the most significant dataset of snow density (SDEN) in the Spanish Pyrenees for on-site manual samples and automatic measurements, in this study, single and multiple linear regression models are evaluated that relate SDEN with intra-annual time dependence and other drivers such as the seasonal accumulated precipitation, 7-day average temperatures, snow depth (SD) and elevation. The seasonal accumulated precipitation presented a more dominant influence than daily precipitation, usually being the second most dominant SDEN driver, followed by temperature. Average temperatures showed the best fitting to SDEN. The results showed similar densification rates ranging widely from $0.7 \times 10^{3} \mathrm{~kg} / \mathrm{L} /$ day to $2 \times 10^{3} \mathrm{~kg} / \mathrm{L} /$ day without showing a spatial pattern. The densification rate for the set of manual samples was set to $1.2 \mathrm{~kg} / \mathrm{L} /$ day, very similar to the set of automatic measurements $(1.3 \mathrm{~kg} / \mathrm{L} /$ day). The results increase knowledge on SDEN in the Pyrenees. The SDEN regression models that are given in this work may allow us, in the future, to estimate SDEN, and consequently Snow Water Equivalent (SWE), using an economical and extensive SD and meteorological network, although the high spatial variability that has been found must be regarded. Estimating a relationship between SDEN and several climate drivers enables us to take into account the impact of climate variability on SDEN.
\end{abstract}

Keywords: snow density; Spanish Pyrenees; ERHIN program; water equivalent; climate variability

\section{Introduction}

Snow in Spain plays a key role in water resource management and occurs essentially in mountainous areas due to Spanish latitudes and meteorological conditions [1-5]. One of the most important Spanish mountain regions is the Pyrenees, which extends about $490 \mathrm{~km}$ between Spain and France, connecting the Atlantic Ocean at its eastern limit with the Mediterranean Sea at its western limit (both of which influence the climate of the Pyrenees), and with Aneto Peak as its highest point (3404 $\mathrm{m}$ altitude). From the different parameters defining snow-related phenomena, snow density (SDEN) relates snow depths (SDs) with the snow water equivalent (SWE). Since SD measurements are much more frequent than the available SWE data, better knowledge and parameterization of SDEN will enable the achievement of a more accurate estimation of the SWE based on SD measurements. Moreover, as wind data become more available, hydrological models can determine a more accurate estimation of forced-convection snowmelt and snow transport, for which SDEN is needed. However, SDEN is a complex parameter that can vary temporally, spatially and even within the snowpack profile in the vertical direction.

The density of freshly fallen snow depends on three main climatic conditions: temperature, wind and humidity. Typical proposed density values for recently fallen snow are found between 0.07 and $0.15 \mathrm{~kg} / \mathrm{L}$, with $0.1 \mathrm{~kg} / \mathrm{L}$ being the most common value [6-8]. 
The density of the new snow can also be estimated linearly, based on air temperature between $-15{ }^{\circ} \mathrm{C}$ and $0{ }^{\circ} \mathrm{C}[9,10]$. However, as SDEN depends on the liquid and snow form proportions, a higher SDEN can be given for fresh snow.

The aggregation of the ice grains begins as soon as snow touches the surface, increasing the snow cover density [11]. This process is known as sintering and plays an important role in snow densification. There are two distinct types of snow metamorphism: constructive metamorphism (recrystallization by vapor diffusion) and destructive metamorphism (equilibrium growth) [12]. A temperature gradient of about $10^{\circ} \mathrm{C} / \mathrm{m}$ is considered a threshold for the initiation of constructive metamorphism $[13,14]$. Liquid water causes destructive metamorphism to take place at a faster rate. Moreover, daily melting cycles associated with solar radiation and atmospheric temperature cause snow crystal metamorphism. This leads to a gradual loss of voids and an irreversible increase in the density of the snow layer over time [15]. At the same time, SDEN affects shortwave radiation penetration in snow. About $80 \%$ of this energy is absorbed in the first 5 to $15 \mathrm{~cm}$ of the snowpack [12]. The range depends on SDEN [16]. Compaction due to gravity should also be considered for SDs above $1 \mathrm{~m}$ [17]. In the Spanish Pyrenees, as the SD is deep for high elevations, this effect may not be negligible. In addition, precipitation over the snowpack will also increase SDEN [18]. These cycles can repeat until the whole snow layer is melted and frozen, turning into ice with an average density of $0.917 \mathrm{~kg} / \mathrm{L}$. However, defining an accurate proportion for each of these processes in the densification rate is not easy.

Different techniques were used to measure or estimate SDEN worldwide [19-23]. Common techniques include conventional on-site manual sampling, the non-destructive snow water equivalent (SWE) determination based on cosmic-ray neutron attenuation (CRN) [24,25], acoustic signal delays [26] and stepped-frequency continuous-wave radar, recently used at the AEMET Formigal-Sarrios test site (Spanish Pyrenees) and implemented in a coherent software-defined radio in the range from $150 \mathrm{MHz}$ to $6 \mathrm{GHz}$ [27]. The use of SWE products derived from satellite microwave radiometer-based measurements, combined with SD measurements, is another alternative technique, but the low spatial resolution of these products may not be suitable for mountainous and complex small catchments [28,29]. Snow pillows are also used for the non-destructive monitoring of SDEN, but they have a complex installation process, maintenance and have uncertainties associated with low SD and irregular snowmelt drainage [30].

Several studies [20,31-34] estimated linear density-time functions or densification rates, providing links to the physical processes. However, density models still need to cope with a high SDEN variability at low SD values, as it can range from low-density new snow to high-density slush. Regarding SDEN's relationship with time, it shows a gradual increase throughout the winter season. Across the western United States, SDEN was found to be location-dependent during early and midwinter, although the snowpack densification daily rate was nearly fixed regardless of the location. Considerable intra-annual variability in SDEN was also reported, with densification trends generally linear, but significantly less year-to-year variation [33]. The low intra-annual variability of SDEN was also observed in southern Canada [35]. In the Swiss Alps, SDEN was found to depend on the season, SD, elevation and location. Elevation had only a minor direct effect [36], as higher SDs at higher sites imply higher SDEN due to compaction in winter, while melting cycles at lower elevations and in the late winter season induce a compensating effect $[21,33,36]$. For the alpine regions in the former Soviet Union and the US, precipitation was the dominant climate variable, followed by average temperature [37].

In the Iberian Peninsula, snow observations and a validated daily gridded snowpack dataset were simulated from downscaled reanalysis [38], calculating SDEN for each time step with different maximum thresholds: $0.3 \mathrm{~kg} / \mathrm{L}$ for cold (non-isothermal) and $0.5 \mathrm{~kg} / \mathrm{L}$ for melting (isothermal) snow conditions [39]. In the central Pyrenees, statistically significant correlations between the SD and other topographic variables with SDEN were found, but they showed a great variability among sites and surveys. The absolute error in the SWE 
estimated from the computed SDEN was less than $15 \%$ and was similar to that obtained by relating SDEN directly to SD [40].

The Spanish Pyrenees hold more than one hundred snow poles and up to thirteen automatic snow monitoring devices, or telenivometers (TNMs), operating since 2008. This instrumentation allows for the study of the seasonal variability of snowfall events [41]. Additionally, the Spanish and Ebro Water Authority have been carrying out on-site SDEN measurements since the early 1990s through the ERHIN program ("Estudio de Recursos Hídricos procedentes de la INnivación"- Study of Snow Water Resources) [42]. TNM data show significant variability in annual SD. Western regions (Atlantic Ocean weather) give the most annual accumulation in the winter months, while eastern regions (Mediterranean weather types) show more homogenous accumulation over winter, spring and late autumn. It is interesting to note that western TNMs also show behaviours similar to that observed for the western coast of the US, which is characterized by plenty of precipitation and relatively high air temperatures, both possible contributors to early season high SDEN [43].

The novelty of this paper remains in the definition of SDEN variability in the Spanish Pyrenees, using the vast amount of data from the ERHIN program obtained from manual sampling and non-destructive automatic measurements. A series of relationships are established with other parameters, and its temporal and spatial variability is characterized. Few comparable works in the world have used such a wide database (SNOTEL or WSL Institute for Snow and Avalanche Research SLF), and there are no similar precedents in the study area. To achieve this goal, a series of single and multiple linear regressions are conducted, relating SDEN with the time evolution variability, seasonal accumulated precipitation, $\mathrm{SD}$, elevation and average temperatures.

\section{Materials and Methods}

The ERHIN program [44] started in 1986, studying snow phenomena in river basins in the mountainous regions of the Pyrenees, Sierra Nevada, the Central System and the Cantabrian Mountains. In this framework, on-site manual SDEN measurements were carried out and a dense network of snow poles and TNMs (SWE and SD non-destructive measurements) were installed. The Pyrenees is the densest region monitored, with 13 TNMs and more than 100 snow poles (Figure 1). The TNMs cover a range about $200 \mathrm{~km}$ long in the Pyrenees and are numbered from west to east.

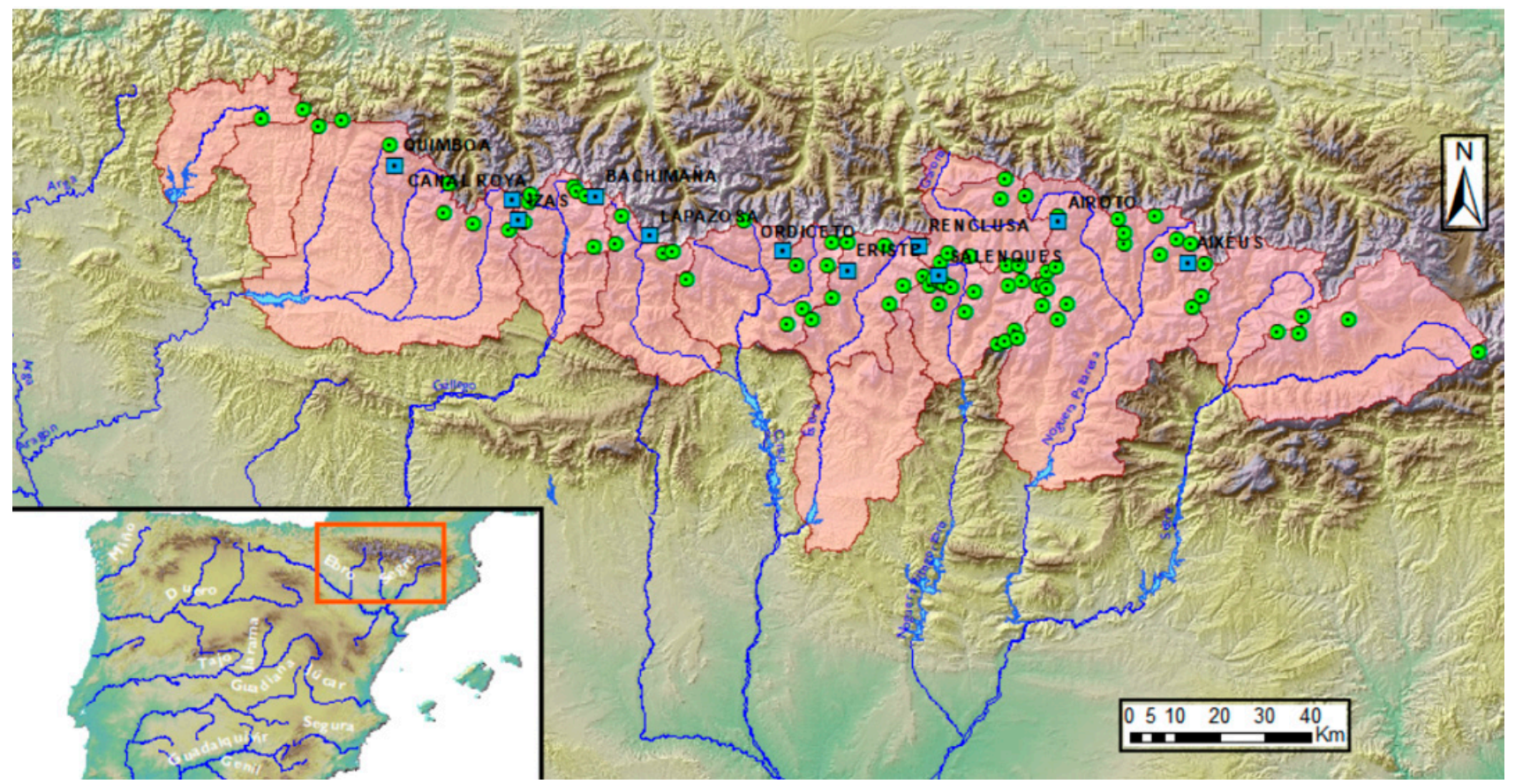

Figure 1. Snow poles (green) and telenivometers (TNM) (blue) network from the ERHIN program [44] in the Pyrenees. 


\subsection{On-Site Manual Sampling and Measurements}

Since 1987, on-site manual SDEN measurements have been carried out at certain snow poles. At the same time, SD measurements were taken for the whole snow pole network. Sampling elevations range from $1440 \mathrm{~m}$ to $2615 \mathrm{~m}$ and cover up to three seasonal campaigns between December and May.

Figure 2 shows a $0.8 \mathrm{~m}$ stackable sampling tube of constant $53.8 \mathrm{~mm}$ diameter inside a section $\left(22.72 \mathrm{~cm}^{2}\right)$ and $2.5 \mathrm{~mm}$ thick, with up to $4 \mathrm{~m}$ of maximum penetration depth. This SWE tube was handmade in 1986 at the Technical University of Valencia. Knowing the weight and dimensions of the core, and therefore its volume, by directly weighing it on a precision weighing scale, the net weight of the snow core is obtained, and the density is calculated.

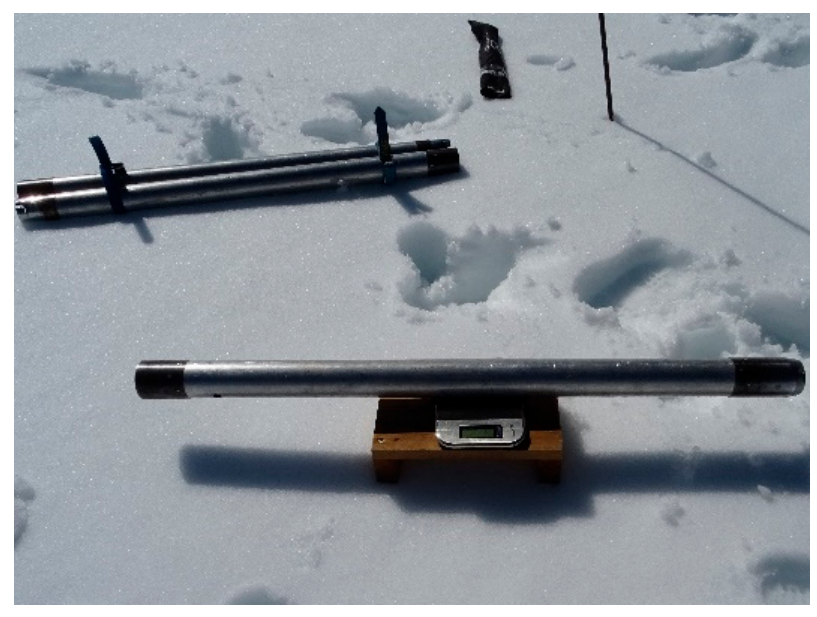

(a)
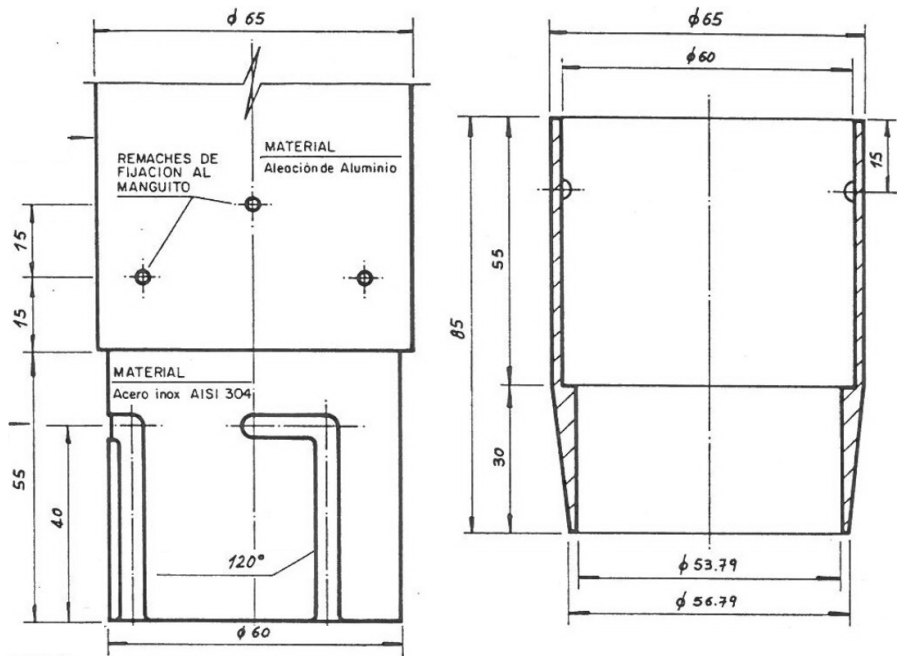

(b)

Figure 2. On-site manual sampling. (a) Snow tubes. (b) Nozzle dimensions.

Table 1 shows the on-site manual sampling and elevation for sites in the same locations as 11 TNM sites. The number of samples is also included. The complete list of 35 snow pole sites and the number of samples are given as supplementary data. Figure 3 shows the elevation distribution for all of the samples taken, ranging from $1810 \mathrm{~m}$ to $2615 \mathrm{~m}$ for snow pole sites.

Table 1. On-site manual sampling sites. Snow poles are in the same locations as the TNM sites.

\begin{tabular}{cccccc}
\hline Name & $\begin{array}{c}\mathbf{X} \\
\text { COORDINATE } \\
\text { ETRS89H30 }\end{array}$ & $\begin{array}{c}\mathbf{Y} \\
\text { COORDINATE } \\
\text { ETRS89H30 }\end{array}$ & $\begin{array}{c}\text { Elevation } \\
(\mathbf{m})\end{array}$ & $\begin{array}{c}\text { No. } \\
\text { Samples }\end{array}$ & $\begin{array}{c}\text { Sampling } \\
\text { Period } \\
\text { (Years) }\end{array}$ \\
\hline 1. Quimboa & 682,767 & $4,748,419$ & 1810 & 13 & $1998-2019$ \\
2. Izas & 710,308 & $4,736,177$ & 2080 & 9 & $2007-2012$ \\
3. Canal Roya & 708,779 & $4,740,716$ & 1860 & 17 & $1987-2019$ \\
4. Bachimaña & 727,394 & $4,741,571$ & 2220 & 61 & $1987-2019$ \\
5. Lapazosa & 739,424 & $4,732,777$ & 2115 & 11 & $2009-2019$ \\
6. Ordiceto & 768,642 & $4,729,429$ & 2380 & 65 & $1987-2015$ \\
7. Renclusa & 799,030 & $4,730,578$ & 2180 & 32 & $1987-2017$ \\
8. Salenques & 803,363 & $4,723,843$ & 2600 & 13 & $2008-2014$ \\
9. Eriste & 783,155 & $4,725,107$ & 2350 & 7 & $2009-2014$ \\
10. Airoto & 829,803 & $4,735,946$ & 2380 & 60 & $1987-2019$ \\
11. Aixéus & 858,381 & $4,726,892$ & 2400 & 66 & $1987-2019$ \\
& Total samples & & 354 & \\
\hline
\end{tabular}




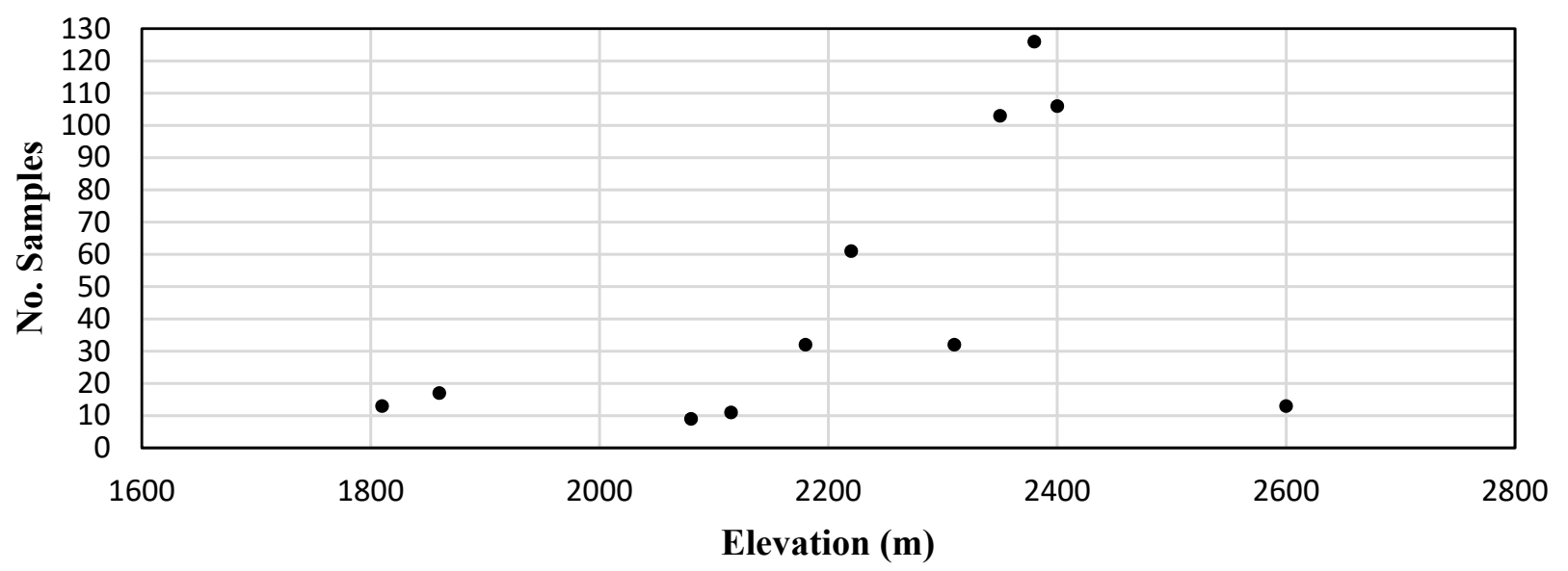

Figure 3. Number of snow density (SDEN) manual samples and elevation distribution.

\subsection{On-Site Non-Destructive Measurements}

First Cosmic-Ray Neutron (CRN) attenuation telenivometers (TNMs) were installed in 2008 along the Spanish Pyrenees (Figure 4), and two more were recently installed in 2015 and 2018. TNMs allow the obtaining of SWE high time resolution data (15 min) and SD vertical data (1 cm resolution). From those values, SDEN can be estimated according to Equation (1):

$$
S D E N=\frac{S W E}{S D}
$$

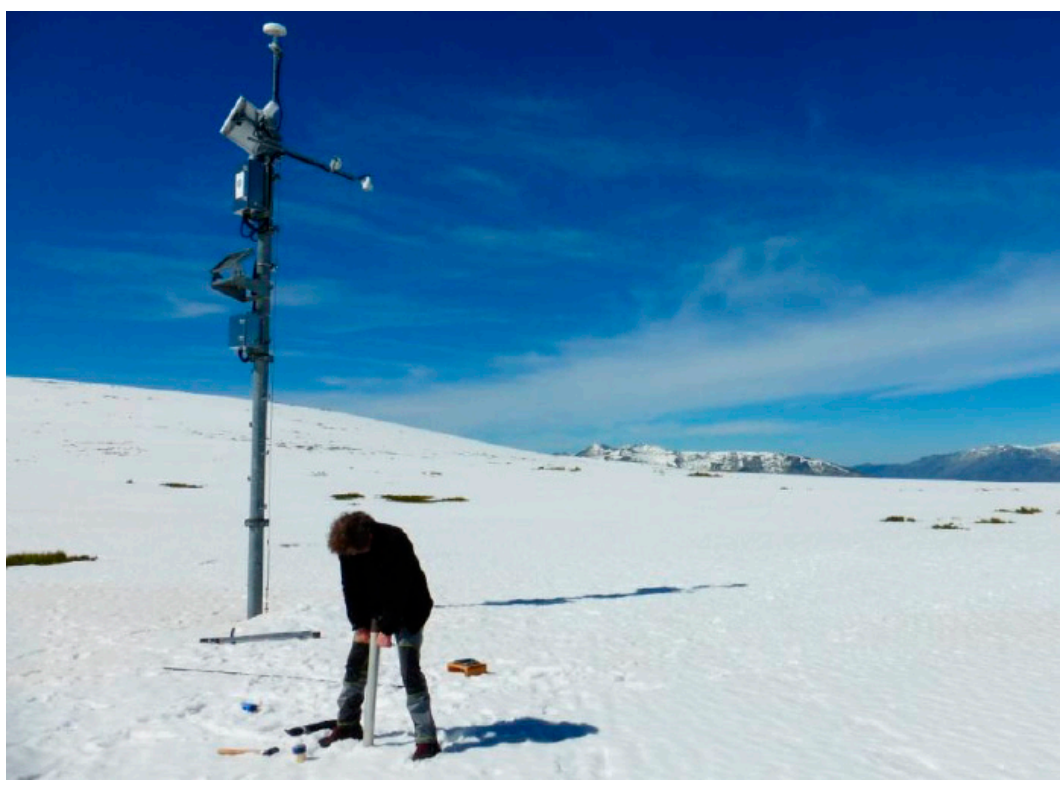

Figure 4. TNM and on-site manual sampling for the snow pole sampler.

Table 2 shows the name, situation, elevation, number of daily samples and sampling period for each TNM, which were located above $1800 \mathrm{~m}$ elevation and with $2600 \mathrm{~m}$ as the maximum elevation. It should be noted that SDEN calculated according to Equation (1) is not sensitive to a higher time resolution. Figure 1 shows the situation of the TNMs in the Pyrenees, (named from west to east), while Figure 5 shows the elevation distribution for the automatic TNM measurements. It is interesting to mention that the Eriste TNM is located at approximately the same distance from the Atlantic Ocean and the Mediterranean Sea. 
Table 2. On-site non-destructive measurements. TNM sites.

\begin{tabular}{cccccc}
\hline Name & $\begin{array}{c}\mathbf{X} \\
\text { COORDINATE } \\
\text { ETRS89H30 }\end{array}$ & $\begin{array}{c}\text { Y } \\
\text { COORDINATE } \\
\text { ETRS89H30 }\end{array}$ & $\begin{array}{c}\text { Elevation } \\
(\mathbf{m})\end{array}$ & $\begin{array}{c}\text { No. } \\
\text { Data }\end{array}$ & $\begin{array}{c}\text { Data } \\
\text { Period } \\
\text { (Years) }\end{array}$ \\
\hline 1. Quimboa & 682,648 & $4,748,214$ & 1810 & 1465 & $2008-2021$ \\
2. Izas & 710,243 & $4,735,937$ & 2080 & 2107 & $2008-2021$ \\
3. Canal Roya & 708,660 & $4,740,541$ & 1971 & 1661 & $2008-2021$ \\
4. Bachimaña & 727,282 & $4,741,345$ & 2220 & 2086 & $2008-2021$ \\
5. Lapazosa & 739,388 & $4,732,579$ & 2140 & 1676 & $2008-2021$ \\
6. Ordiceto & 768,527 & $4,729,209$ & 2380 & 2043 & $2008-2021$ \\
7. Renclusa & 798,925 & $4,730,377$ & 2175 & 1737 & $2008-2020$ \\
8. Salenques & 803,294 & $4,723,655$ & 2600 & 263 & $2008-2010$ \\
9. Eriste & 783,048 & $4,724,896$ & 2350 & 2049 & $2009-2021$ \\
10. Airoto & 829,707 & $4,735,723$ & 2380 & 2004 & $2008-2021$ \\
11. Aixeus & 858,269 & $4,726,759$ & 2400 & 2010 & $2008-2021$ \\
14. Sarrios- & 713,384 & $4,737,624$ & 1800 & 643 & $2015-2021$ \\
Formigal & 799,420 & $4,731,387$ & 1930 & 317 & $2018-2021$ \\
15. Besurta & Total samples & & 21,257 & \\
\hline
\end{tabular}

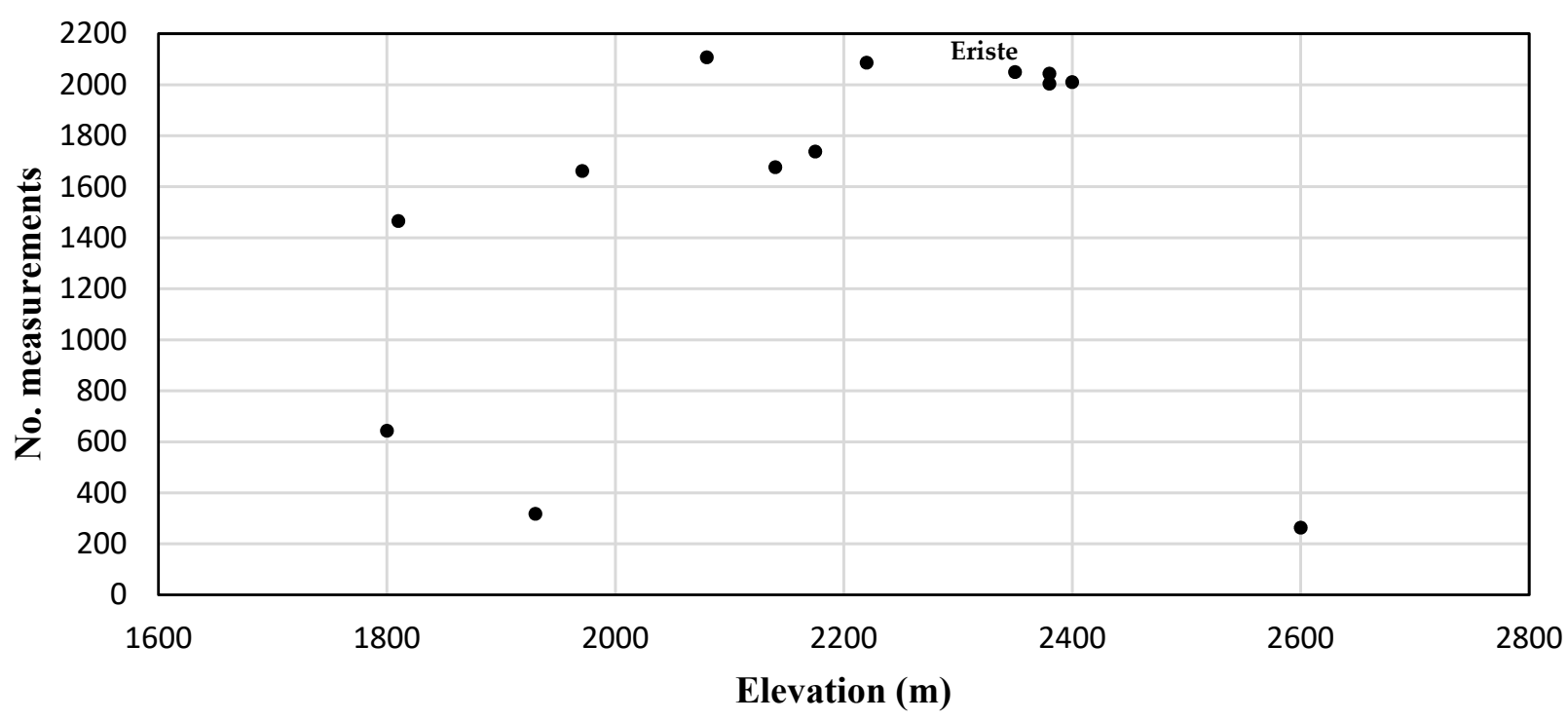

Figure 5. Number of SDEN automatic TNM measurements and elevation distribution.

Although the TNMs have been operating for a shorter period than the period covered by manual samples, daily data were registered, with more than 20,000 samples and officially provided by the Ebro Water Authority (http:/ / www.saihebro.com/saihebro/index.php? url=/datos/usos/mapa:TNG/tipoestacion:TN accessed on 4 June 2021). Additionally, the maximum, average and minimum daily temperatures were available.

\subsection{Other Data and Sources of Error}

Supplementary Materials are provided for both on-site manual sampling and on-site non-destructive (TNM) daily measurements.

The daily data for precipitation from the closest meteorological stations within the same period as the TNM measurements are also given in the Supplementary Material.

The sources of error and uncertainties associated with snow sampling include the loss of part of the sample due to snowpack collapse when the sampler encounters hard layers. When the sampler is extracted from the snowpack for weighing, snow can also be lost [45] or stuck to the outside of the sampler. These errors may be increased by a snowpack with ice layers that give the false perception of reaching the ground, basal ice and layers of depth 
hoar and non-cohesive crystals. New snow or wet snow can also increase sampling errors, especially if the observer is collecting core samples to be weighed later rather than using a spring balance and tube cradle. The experience of the observer plays an important role in reducing potential errors due to human failure. Depending on the temperature, new and wet snow will tend to stick in the tube, and this will result in an underestimation of the SWE, which could exceed $10 \%$. Smaller diameter cutters (down to $20 \mathrm{~cm}^{2}$ ) were more prone to plugging as they encountered ice lenses, and they were more likely to induce the collapse of non-cohesive layers under the cutter, resulting in an underestimation of the total SWE [46]. The ideal cutter area was about $30 \mathrm{~cm}^{2}$, demonstrated by the low error percentage of the ESC30 sampler, which ranged from a $5 \%$ overestimation to a $2 \%$ underestimation [47]. The uncertainty of density measurements in non-ideal snow conditions is approximately within 10 to $15 \%$ [48]. As a control measure, random validation tests were carried out for manual samples and measurement protocols were followed [46].

Errors in TNM measurements can occur due to non-environmental issues such as instrument malfunction and incorrect instrument calibration (or calibration drift), CRN uncertainties due to changes in mid-season soil moisture levels and the undervaluation of precipitation and gaps or false null data from other meteorological variables. In this regard, TNM data are periodically calibrated with manual sampling during late snow conditions [42].

\subsection{Analysis Methodology}

A previous screening process was carried out, with the identification of outliers (a range check for reasonable values between zero and the maximum possible SDEN for the site), gaps and null data, discarding sites with little information or information that was not representative.

TNM measurements are fully automated and, even though they are frequently calibrated, are not quality controlled. Thus, the calculated SDEN values that significantly exceeded the expected maximum and minimum values at each site were removed. The number of samples for each TNM is given after quality-control procedures. All negative and null values were eliminated from the records, for both the SWE and SD, which are necessary to estimate SDEN. Consequently, TNMs numbers 8, 14 and 15 (Salenques, Sarrios-Formigal and Besurta) were discarded.

Manual samples, much less prone to uncertainties [37], underwent a similar screening process. On-site manual sample sites with enough data in the same location as TNM sites were selected and pooled. The previous screening process reduced 35 on-site manual sites with 841 samples to five on-site manual sites matching TNM sites with 284 samples. SDEN statistics were calculated for both manual samples and automatic measurements during the entire year (annual period), as well as for the accumulation period (winter snow, until $21 \mathrm{March}$ ) and for the melting period (spring snow, from 21 March).

Automatic TNM sites with a significant correlation between SDEN and the day of the year (time evolution) were selected and grouped (the set of TNMs) for automatic TNM measurements, where day 1 corresponds to 1 October. The results were compared with the SDEN-day of the year correlation for manual samples.

Independent variables were analysed for the selected automatic TNM sites. The dominant climatological drivers of annual SDEN variability were extracted by establishing single linear regressions between each of the predictor terms and SDEN. The selected climate and spatial predictors include the time evolution, precipitation, accumulated precipitation, $\mathrm{SD}$ and average temperature.

Multiple linear regressions (MLRs) between SDEN and these predictors were studied for automatic measurements and compared with manual samples. The effect of elevation on the grouped series (the set of TNMs) was evaluated. Predictors were added progressively in the MLR model from more to less dominant with a significance threshold of 0.05 . 


\section{Results}

In this section, the SDEN results are analysed, identifying dominant climatological variables and studying MLR models for SDEN. Results from both the manual and automatic measurements are presented.

\subsection{SDEN Statistics}

Table 3 shows a summary of the SDEN statistics obtained by on-site manual data for two annual periods, winter or early season (until 21 March) and spring or late season (21 March-30 June). The word "set" refers to all grouped data.

Table 3. SDEN statistics for the most representative manual samples in the same location as TNM sites and for the set of samples.

\begin{tabular}{ccccccc}
\hline Name & $\begin{array}{c}\text { Average } \\
\text { (Annual) }\end{array}$ & $\begin{array}{c}\text { C. V. } \\
\text { (Annual) }\end{array}$ & $\begin{array}{c}\text { Average } \\
\text { (Winter) }\end{array}$ & $\begin{array}{c}\text { C. V. } \\
\text { (Winter) }\end{array}$ & $\begin{array}{c}\text { Average } \\
\text { (Spring) }\end{array}$ & $\begin{array}{c}\text { C. V. } \\
\text { (Spring) }\end{array}$ \\
\hline 4. Bachimaña & 0.396 & $1.82 \%$ & 0.351 & $1.82 \%$ & 0.442 & $0.90 \%$ \\
6. Ordiceto & 0.396 & $1.72 \%$ & 0.349 & $1.23 \%$ & 0.451 & $0.93 \%$ \\
7. Renclusa & 0.368 & $1.96 \%$ & 0.306 & $0.88 \%$ & 0.437 & $0.71 \%$ \\
10. Airoto & 0.382 & $1.60 \%$ & 0.344 & $1.69 \%$ & 0.427 & $0.68 \%$ \\
$\begin{array}{c}\text { 11. Aixéus } \\
\text { Set of Manual }\end{array}$ & 0.386 & $1.53 \%$ & 0.337 & $0.92 \%$ & 0.427 & $1.05 \%$ \\
Samples & 0.394 & $1.75 \%$ & 0.348 & $1.47 \%$ & 0.443 & $0.93 \%$ \\
\hline
\end{tabular}

The average SDEN and coefficient of variation (C.V.) were very similar among sites for every period, without spatial patterns from east to west locations. Renclusa showed the lowest average SDEN and the highest C.V. due to a very low winter average SDEN and very marked differences between early and late season snow. Bachimaña and Ordiceto showed the highest average SDEN. As expected, the average SDEN value was greater for the late season (spring) than for the early season (winter). The C.V. is small for all sites studied and the set of samples, being the greatest during the early season (winter).

Table 4 shows a summary of the SDEN statistics obtained from TNM data for two annual periods, winter or early season (until 21 March) and spring or late season (21 March-30 June). The set of TNMs refers to TNMs numbers 1, 2, 4, 6, 7 and 9.

Table 4. SDEN statistics for TNM data and for data from the set of TNMs.

\begin{tabular}{ccccccc}
\hline Name & $\begin{array}{c}\text { Average } \\
\text { (Annual) }\end{array}$ & $\begin{array}{c}\text { C. V. } \\
\text { (Annual) }\end{array}$ & $\begin{array}{c}\text { Average } \\
\text { (Winter) }\end{array}$ & $\begin{array}{c}\text { C. V. } \\
\text { (Winter) }\end{array}$ & $\begin{array}{c}\text { Average } \\
\text { (Spring) }\end{array}$ & $\begin{array}{c}\text { C. V. } \\
\text { (Spring) }\end{array}$ \\
\hline 1.Quimboa & 0.389 & $3.80 \%$ & 0.344 & $3.17 \%$ & 0.511 & $1.04 \%$ \\
2. Izas & 0.36 & $1.97 \%$ & 0.309 & $1.04 \%$ & 0.435 & $0.80 \%$ \\
3. Canal Roya & 0.348 & $1.67 \%$ & 0.325 & $1.32 \%$ & 0.400 & $1.40 \%$ \\
4. Bachimaña & 0.368 & $2.53 \%$ & 0.332 & $2.11 \%$ & 0.455 & $0.95 \%$ \\
5. Lapazosa & 0.364 & $3.13 \%$ & 0.334 & $2.81 \%$ & 0.438 & $1.92 \%$ \\
6. Ordiceto & 0.385 & $4.60 \%$ & 0.312 & $2.66 \%$ & 0.512 & $1.29 \%$ \\
7. Renclusa & 0.365 & $2.52 \%$ & 0.326 & $1.47 \%$ & 0.462 & $1.43 \%$ \\
9. Eriste & 0.435 & $2.23 \%$ & 0.398 & $1.61 \%$ & 0.508 & $1.63 \%$ \\
10. Airoto & 0.383 & $3.55 \%$ & 0.357 & $3.31 \%$ & 0.449 & $2.67 \%$ \\
11. Aixeus & 0.386 & $3.83 \%$ & 0.360 & $4.36 \%$ & 0.440 & $1.95 \%$ \\
Set of TNMs & 0.384 & $3.07 \%$ & 0.337 & $2.26 \%$ & 0.480 & $1.44 \%$ \\
\hline
\end{tabular}

As for manual samples, except for Eriste, the TNM data showed very similar SDEN averages among sites for every period, without spatial patterns from east to west locations. Eriste showed the highest average SDEN, while Canal Roya's average SDEN was the lowest; the C.V. is again small, with all TNMs below $5 \%$, but there were some differences among sites, since the amount of data between them is variable. The Ordiceto TNM showed 
the greatest C.V. Once again, the C.V. was usually greater for the early season (winter) than for the late season (spring).

A comparison of statistics between manual and automatic data (see Table 5) showed small differences in terms of the average SDEN, although the C.V. values are higher for the automatic data. The set of manual samples and the set of TNM data show small differences for the average SDEN, especially for the annual and early-season periods. Renclusa showed the lowest annual SDEN average for both the manual and automatic data, while the highest annual average SDEN was represented by different locations for each technique.

Table 5. SDEN statistics comparison between automatic data for TNM sites in the same location as manual samples.

\begin{tabular}{ccccccc}
\hline Name & $\begin{array}{c}\text { Average } \\
\text { (Annual) }\end{array}$ & $\begin{array}{c}\text { C. V. } \\
\text { (Annual) }\end{array}$ & $\begin{array}{c}\text { Average } \\
\text { (Winter) }\end{array}$ & $\begin{array}{c}\text { C. V. } \\
\text { (Winter) }\end{array}$ & $\begin{array}{c}\text { Average } \\
\text { (Spring) }\end{array}$ & $\begin{array}{c}\text { C. V. } \\
\text { (Spring) }\end{array}$ \\
\hline 4. Bachimaña & $107.6 \%$ & $71.9 \%$ & $105.7 \%$ & $86.3 \%$ & $97.1 \%$ & $94.7 \%$ \\
6. Ordiceto & $102.9 \%$ & $37.4 \%$ & $111.9 \%$ & $46.2 \%$ & $88.1 \%$ & $72.1 \%$ \\
7. Renclusa & $100.8 \%$ & $77.8 \%$ & $93.9 \%$ & $59.9 \%$ & $94.6 \%$ & $49.7 \%$ \\
10. Airoto & $99.7 \%$ & $45.1 \%$ & $96.4 \%$ & $51.1 \%$ & $95.1 \%$ & $25.5 \%$ \\
11. Aixeus & $100.0 \%$ & $39.9 \%$ & $93.6 \%$ & $21.1 \%$ & $97.0 \%$ & $53.8 \%$ \\
Set of TNMs & $102.6 \%$ & $57.0 \%$ & $103.3 \%$ & $65.0 \%$ & $92.3 \%$ & $64.6 \%$ \\
\hline
\end{tabular}

\subsection{Most Representative Automatic TNM Sites}

The most representative automatic TNM sites were selected and grouped (the set of TNMs) for the automatic TNM data, with a significant correlation between SDEN and the day of the year (intra-annual time dependence), where day 1 corresponds to 1 October. An intra-annual time dependence for SDEN was found using Equation (2):

$$
S D E N=A \cdot d a y+B
$$

The coefficients $A$ and $B$ are given in Table 6 along with the site elevation of each TNM and the average elevation of the set of TNMs, with the coefficient of determination $\left(R^{2}\right)$ being computed in each case. The relationship found is important as it describes SDEN when data from other climatic variables are not available. The coefficient $A$ represents the densification rate, ranging from $0.7 \times 10^{-3} \mathrm{~kg} / \mathrm{L} /$ day to $2 \times 10^{-3} \mathrm{~kg} / \mathrm{L} /$ day; the coefficient $B$ represents the initial SDEN, ranging from $0.1 \mathrm{~kg} / \mathrm{L}$ to $0.3 \mathrm{~kg} / \mathrm{L}$. Neither of the two parameters shows a spatial pattern.

Table 6. SDEN intra-annual time dependence for automatic measurements. Bold letters are used for selected sites for the Set of TNMs.

\begin{tabular}{cccccc}
\hline Name & A (day) & $\mathbf{B}$ & $\begin{array}{c}\text { Elevation } \\
(\mathbf{m})\end{array}$ & $\boldsymbol{R}^{\mathbf{2}}$ & $\begin{array}{c}\text { Sampling } \\
\text { Period } \\
\text { (Years) }\end{array}$ \\
\hline $\begin{array}{c}\text { 1.Quimboa } \\
\text { 2. Izas }\end{array}$ & 0.0020 & 0.112 & 1810 & 0.61 & $2008-2021$ \\
3. Canal Roya & 0.0012 & 0.177 & 2080 & 0.64 & $2008-2021$ \\
4. Bachimaña & 0.0007 & 0.252 & 1971 & 0.18 & $2008-2021$ \\
5. Lapazosa & 0.0011 & 0.224 & 2220 & 0.4 & $2008-2021$ \\
6. Ordiceto & 0.0009 & 0.242 & 2140 & 0.17 & $2008-2021$ \\
7. Renclusa & 0.0020 & 0.090 & 2380 & 0.73 & $2008-2021$ \\
9. Eriste & 0.0018 & 0.1 & 2175 & 0.15 & $2008-2020$ \\
10. Airoto & 0.0009 & 0.303 & 2350 & 0.27 & $2009-2021$ \\
11. Aixeus & 0.0008 & 0.280 & 2380 & 0.13 & $2008-2021$ \\
Set of TNMs & 0.0007 & 0.285 & 2400 & 0.10 & $2008-2021$ \\
& 0.0013 & 0.196 & 2187 & 0.44 & $2008-2020$ \\
\hline
\end{tabular}


Automatic TNM sites with a significant coefficient of determination $\left(R^{2}\right)$ were selected and grouped (the set of TNMs) for automatic TNM measurements. The densification rate for the data from the set of TNMs is set to $1.3 \times 10^{-3} \mathrm{~kg} / \mathrm{L} /$ day, with an initial SDEN of $0.196 \mathrm{~kg} / \mathrm{L}$. Ordiceto, placed in the central Pyrenees, showed the highest densification rate and coefficient of determination $\left(R^{2}\right)$ and the lowest initial SDEN. Aixeus, in the eastern part of the Pyrenees, showed the lowest densification rate and coefficient of determination $\left(R^{2}\right)$, while the highest initial SDEN was found in Eriste. Canal Roya, Bachimaña, Lapazosa, Eriste, Airoto and Aixeus showed low densification rates and high initial SDENs, while Quimboa, Izas, Ordiceto and Renclusa showed the opposite behaviour. Therefore, no spatial pattern can be observed.

Regarding $\left(R^{2}\right)$, TNMs numbers 1, 2, 4, 6, 7 and 9 are selected. TNM number 9 (Eriste) is selected as the most representative of the eastern part of the Pyrenees. Figure 6 shows the SDEN intra-annual time dependence for the selected TNMs and the trend line for the set of TNMs.

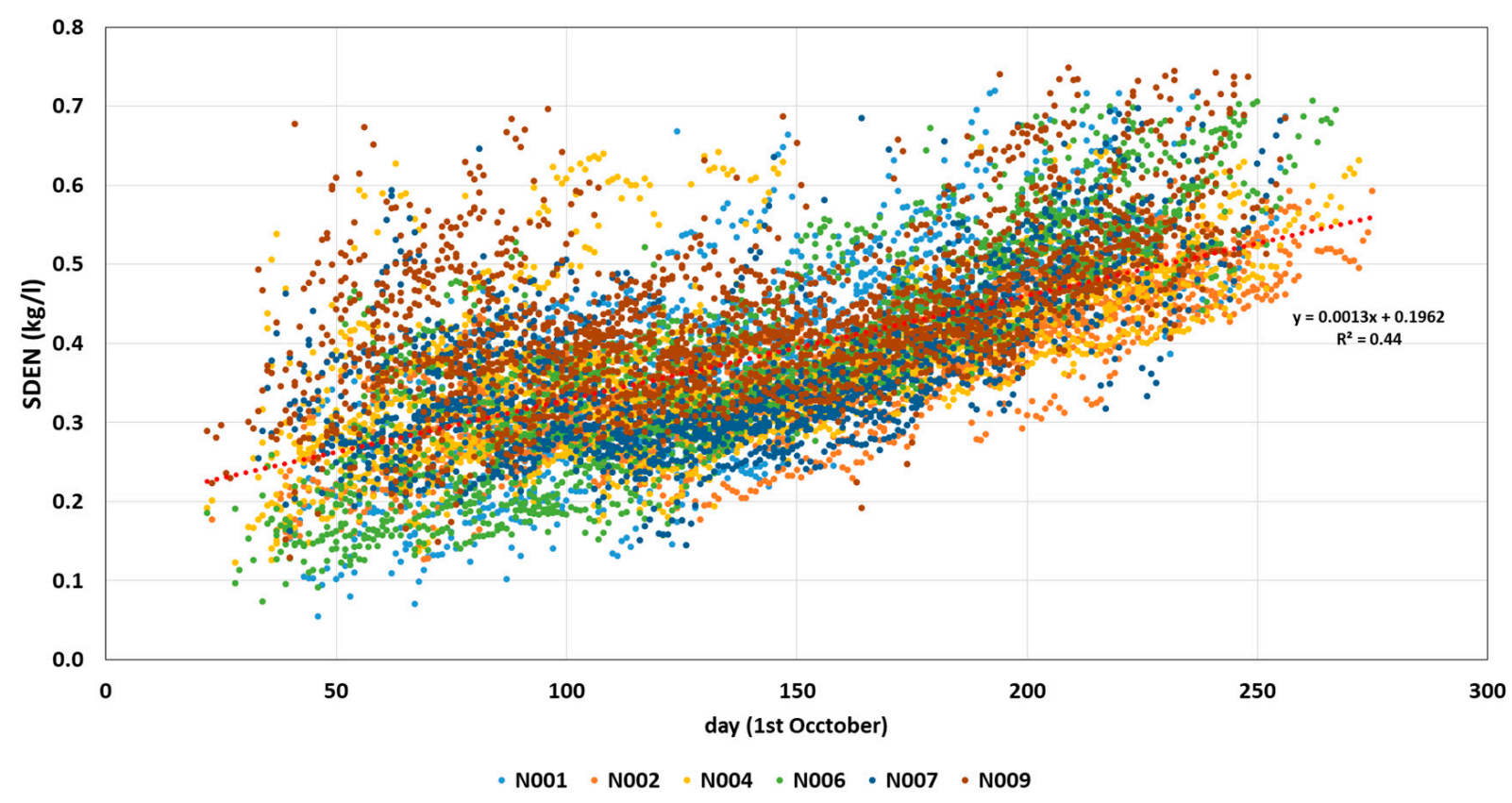

Figure 6. SDEN intra-annual time dependence for selected TNM measurements. Red trend line for the set of TNMs.

Table 7 shows the values of the coefficients $A$ and $B$ for manual sampling in the most representative TNM sites and the set of manual samples, which enables the establishment of the intra-annual time dependence of SDEN using Equation (2). The average elevation for the set of manual samples and the coefficient of determination $\left(R^{2}\right)$ are shown, too. For manual samples, the densification rates and an initial SDEN range have less variability than the automatic measurements, from $1.1 \times 10^{-3} \mathrm{~kg} / \mathrm{L} /$ day to $1.8 \times 10^{-3} \mathrm{~kg} / \mathrm{L} /$ day and from $0.13 \mathrm{~kg} / \mathrm{L}$ to $0.19 \mathrm{~kg} / \mathrm{L}$, respectively. The densification rate from the set of manual samples is set to $1.2 \times 10^{-3} \mathrm{~kg} / \mathrm{L} /$ day, with an initial SDEN of $0.189 \mathrm{~kg} / \mathrm{L}$, showing values very similar to but lower than the values of the automatic measurements. Common sites for both manual and TNM data are Bachimaña, Ordiceto and Renclusa. Bachimaña showed the same coefficient of determination but a higher densification rate and a lower initial SDEN for manual samples than for automatic data. Ordiceto showed a lower coefficient of determination and densification rate, but a higher initial SDEN for the manual samples than for the automatic data. Renclusa had a higher coefficient of determination and the same densification rate, but a lower initial SDEN. 
Table 7. SDEN intra-annual time dependence for manual sampling in the most representative TNM sites and the set of manual samples. Bold letters are used for manual samples in the same locations as selected TNM sites.

\begin{tabular}{cccccc}
\hline Name & A (day) & B & $\begin{array}{c}\text { Elevation } \\
(\mathbf{m})\end{array}$ & $\boldsymbol{R}^{\mathbf{2}}$ & $\begin{array}{c}\text { No. } \\
\text { Samples }\end{array}$ \\
\hline 4. Bachimaña & 0.0013 & 0.157 & 2220 & 0.4 & 61 \\
6. Ordiceto & 0.0016 & 0.126 & 2380 & 0.57 & 65 \\
7. Renclusa & 0.0018 & 0.054 & 2180 & 0.73 & 32 \\
10. Airoto & 0.0011 & 0.188 & 2380 & 0.35 & 60 \\
11. Aixéus & 0.0011 & 0.180 & 2400 & 0.34 & 66 \\
Set of Manual & 0.0012 & 0.189 & 2268 & 0.34 & 840 \\
samples & & & & & \\
\hline
\end{tabular}

Figure 7 displays the linear time dependence of SDEN for the set of manual samples.

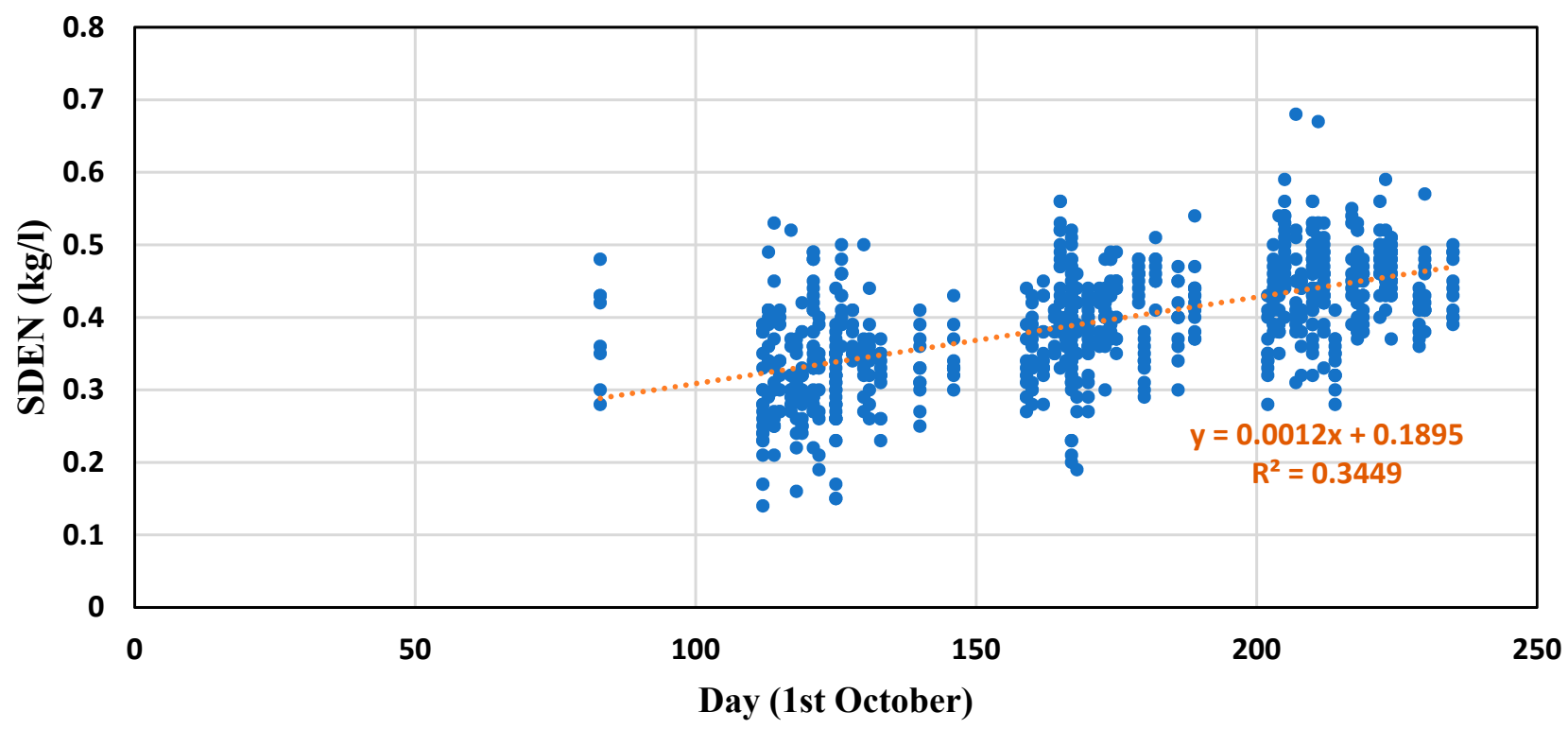

Figure 7. SDEN time dependence for on-site manual sampling. Trend line for the set of manual samples.

\subsection{Identification of Dominant Variables}

In addition to the time dependence, the selected predictors included the SD $(\mathrm{cm})$, seasonal accumulated daily precipitation (PPacum $(\mathrm{mm})$ ) and 7-day average temperature (Tave7d) $\left({ }^{\circ} \mathrm{C} / 7\right.$ days). The seasonal accumulated precipitation was taken into account from the first day that snow accumulation starts and presented a more dominant influence than the daily precipitation, as SDEN depends on historical intra-annual evolution. The 7-day average temperatures have shown the best fitting to SDEN. SDEN depends on punctual temperatures for the accumulation process, but during melting cycles, average temperatures may describe it better [33]. The effects of the maximum and average daily temperatures were similar, while the minimum daily temperature was less dominant. Average daily temperatures were chosen, as they may be more available. Table 8 shows the correlation values, with the intra-annual time dependence and seasonal accumulated precipitation being the most dominant variables. 
Table 8. SDEN correlation coefficients $\left(\mathrm{R}^{2}\right)$ for TNM selected sites.

\begin{tabular}{ccccc}
\hline Name & $\begin{array}{c}\text { Time } \\
\text { Dependence } \\
\text { (day) }\end{array}$ & $\begin{array}{c}\text { PPacum } \\
(\mathbf{m m})\end{array}$ & $\begin{array}{c}\text { Tave7d } \\
\left({ }^{\circ} \mathbf{C} / 7 \text { days) }\right.\end{array}$ & $\begin{array}{c}\text { SD } \\
(\mathbf{c m})\end{array}$ \\
\hline 1. Quimboa & 0.61 & 0.58 & 0.18 & 0 \\
2. Izas & 0.64 & 0.47 & 0.37 & 0.03 \\
4. Bachimaña & 0.4 & 0.21 & 0.20 & 0 \\
6. Ordiceto & 0.73 & 0.44 & 0.21 & 0.14 \\
7. Renclusa & 0.15 & 0 & 0.38 & 0 \\
9. Eriste & 0.27 & 0.13 & 0.19 & 0.07 \\
Set of TNMs & 0.44 & 0.25 & 0.19 & 0 \\
\hline
\end{tabular}

For the Quimboa TNM, the PPacum driver was the most dominant, while Tave7d was the most dominant for the Renclusa TNM. For the rest of the selected TNMs (Izas, Bachimaña, Ordiceto and Eriste), the intra-annual time dependence was the main variable.

The SDEN linear correlation with SD is almost negligible, except for the Ordiceto and Eriste TNMs. However, it may give useful information, as the significance threshold of SDEN is reduced for high SD values. Figure 8 represents SDEN's variability on SD for the set of TNMs, divided into an early-mid season snowpack and mid-late season snowpack. As observed, SDEN has a wide range of values with low SD, especially for the early season snowpack, reducing SDEN variability as SD increases.

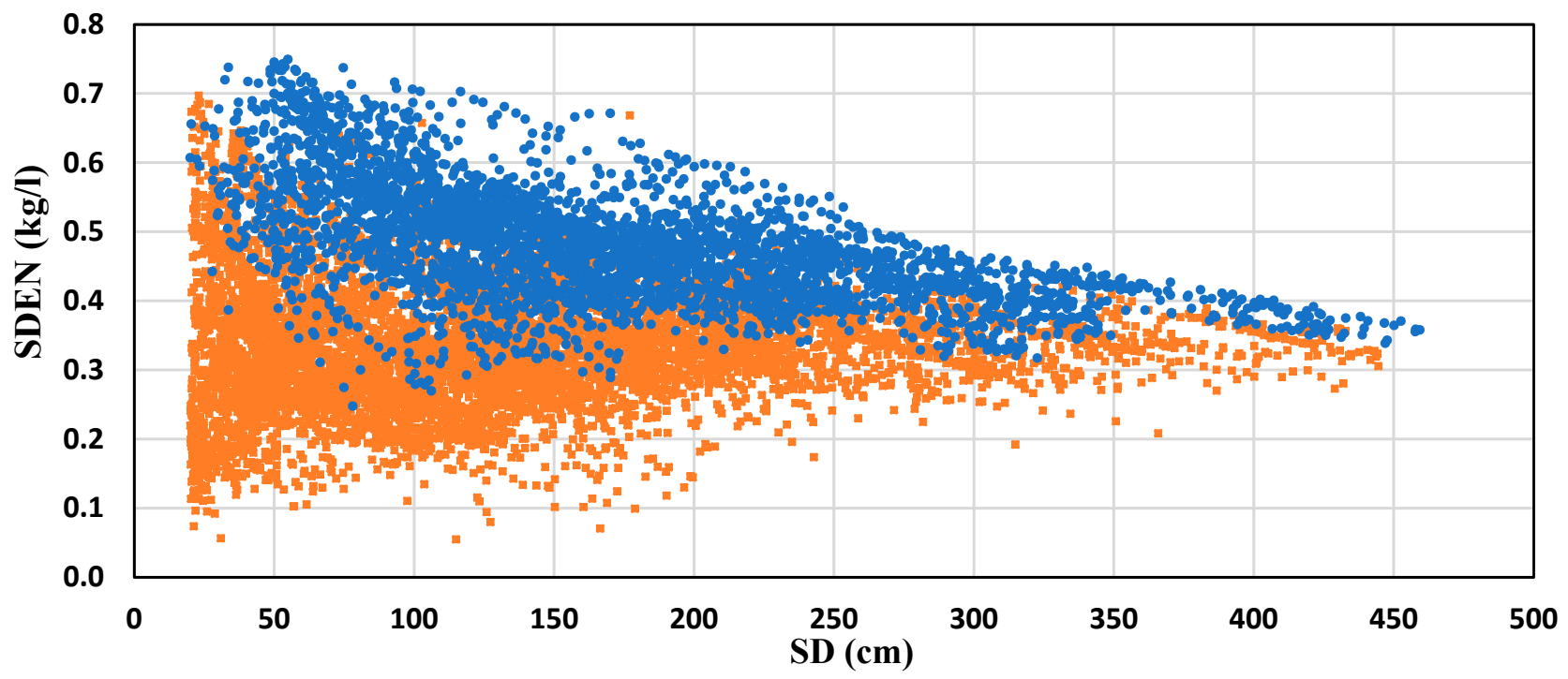

Figure 8. SDEN variability with SD for the set of TNMs. Blue, front-Late season snowpack (21 March-21 June); Orange, back-Early season snowpack (21 October-21 March).

\subsection{Multiple Linear Regressions (MLRs)}

The MLRs between SDEN and the evaluated predictors were studied for the automatic measurements and compared with the manual samples. Those MLRs follow Equation (3):

$$
S D E N=A_{1} \cdot d a y+A_{2} \cdot P \text { Pacum }+A_{3} \cdot \text { Tave } 7 d+A_{4} \cdot S D+B
$$

The coefficients $A_{i}$ are given in Table 9 for each site studied. As mentioned before, predictors were added progressively in the MLR model from more to less dominant, indicating the incrementally adjusted correlation coefficient (adjusted $R^{2}$ ). Moreover, the 
effect of elevation for the data from the set of TNMs was also evaluated as a driver, thus the MLR followed Equation (4):

$$
\text { SDEN }=A_{1} \cdot \text { day }+A_{2} \cdot \text { PPacum }+A_{3} \cdot \text { Tave } 7 d+A_{4} \cdot S D+A_{5} \cdot \text { elevation }+B
$$

Table 9. Optimum SDEN multiple linear regression model for TNM selected sites and the set of TNMs (TNMs Nos. 1, 2, 4, 6, 7 and 9). Regression coefficients $\left[A_{i}, B\right]$ and the incrementally adjusted correlation coefficient $\left(R_{i}{ }^{2}\right)$. Bold letters are used for the final adjusted correlation coefficient $\left(R^{2}\right)$ for Equations (3) and (4).

\begin{tabular}{|c|c|c|c|c|c|c|}
\hline Name & $\begin{array}{c}A_{1} \\
\text { (day) }\end{array}$ & $\begin{array}{c}A_{2} \\
\text { (PPacum) }\end{array}$ & $\begin{array}{c}A_{3} \\
\text { (Tave7d) }\end{array}$ & $\begin{array}{c}A_{4} \\
\text { (SD) }\end{array}$ & $\begin{array}{c}A_{5} \\
\text { (Elevation) }\end{array}$ & B \\
\hline 1.Quimboa & $\begin{array}{c}{\left[1.056 \times 10^{-3}\right]} \\
(0.606)\end{array}$ & $\begin{array}{c}{\left[0.205 \times 10^{-3}\right]} \\
(0.648)\end{array}$ & $\begin{array}{c}\left.4.783 \times 10^{-3}\right] \\
(0.681)\end{array}$ & $\begin{array}{c}{\left[-0.190 \times 10^{-3}\right]} \\
(\mathbf{0 . 6 9 1 )}\end{array}$ & - & [0.187] \\
\hline 2. Izas & 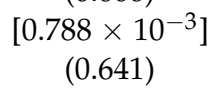 & $\begin{array}{c}{\left[0.078 \times 10^{-3}\right]} \\
(0.652)\end{array}$ & $\begin{array}{c}{\left[5.520 \times 10^{-3}\right]} \\
(0.732)\end{array}$ & $\begin{array}{c}{\left[-0.057 \times 10^{-3}\right]} \\
\mathbf{( 0 . 7 3 5 )}\end{array}$ & - & [0.218] \\
\hline 4. Bachimaña & 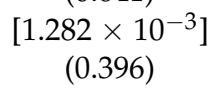 & $\begin{array}{c}{\left[0.020 \times 10^{-3}\right]} \\
(0.414)\end{array}$ & $\begin{array}{c}{\left[2.317 \times 10^{-3}\right]} \\
(0.468)\end{array}$ & $\begin{array}{c}{\left[-0.480 \times 10^{-3}\right]} \\
\mathbf{( 0 . 5 4 2 )}\end{array}$ & - & [0.257] \\
\hline 6. Ordiceto & $\begin{array}{c}{\left[2.295 \times 10^{-3}\right]} \\
(0.733)\end{array}$ & $\begin{array}{c}{\left[0.035 \times 10^{-3}\right]} \\
(0.780)\end{array}$ & $\begin{array}{c}{\left[3.287 \times 10^{-3}\right]} \\
(0.803)\end{array}$ & $\begin{array}{c}{\left[-0.440 \times 10^{-3}\right]} \\
\mathbf{( 0 . 8 2 5 )}\end{array}$ & - & [0.096] \\
\hline 7. Renclusa & 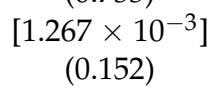 & $(0.00)$ & $\begin{array}{c}{\left[7.242 \times 10^{-3}\right]} \\
(0.514)\end{array}$ & $\begin{array}{c}{\left[-0.694 \times 10^{-3}\right]} \\
\mathbf{( 0 . 6 3 1 )}\end{array}$ & - & [0.271] \\
\hline 9. Eriste & $\begin{array}{c}{\left[1.263 \times 10^{-3}\right]} \\
(0.271)\end{array}$ & $\begin{array}{c}{\left[0.0475 \times 10^{-3}\right]} \\
(0.280)\end{array}$ & $\begin{array}{c}{\left[2.505 \times 10^{-3}\right]} \\
(0.356)\end{array}$ & $\begin{array}{c}{\left[-1.005 \times 10^{-3}\right]} \\
\mathbf{( 0 . 6 0 0 )}\end{array}$ & - & [0.365] \\
\hline Set of TNMs & $\begin{array}{c}{\left[1.268 \times 10^{-3}\right]} \\
(0.459)\end{array}$ & $\begin{array}{c}{\left[0.0685 \times 10^{-3}\right]} \\
(0.460)\end{array}$ & $\begin{array}{c}{\left[4.266 \times 10^{-3}\right]} \\
(0.503)\end{array}$ & $\begin{array}{c}{\left[-0.352 \times 10^{-3}\right]} \\
\mathbf{( 0 . 5 6 2 )}\end{array}$ & $\begin{array}{c}{\left[0.0482 \times 10^{-5}\right]} \\
\mathbf{( 0 . 5 6 8 )}\end{array}$ & [0.130] \\
\hline
\end{tabular}

Therefore, $\left(R^{2}\right)$ for $A_{4}(\mathrm{SD})$ represents the adjusted correlation coefficient for the MLR model and Equation (3), while $\left(R^{2}\right)$ for $A_{5}$ (Elevation) represents the adjusted correlation coefficient for the MLR model and Equation (4).

The MLR models improve the correlation compared with the single linear regression for intra-annual temporal dependence $\left(A_{1}\right)$, especially for those with a low adjusted $R^{2}$, such as the Renclusa and Eriste TNMs. The adjusted $R^{2}$ ranges from 0.54 for the Bachimaña TNM to 0.83 for the Ordiceto TNM. The seasonal accumulated precipitation (PPacum) improves the correlation for the Quimboa and Ordiceto TNMs. The 7-day average temperature (Tave7d) plays a key role in describing SDEN for the Renclusa TNM and influences SDEN moderately for the Izas and Eriste TNMs. SD had an important effect in describing SDEN for the Bachimaña, Renclusa and especially the Eriste TNMs, and consequently, in the overall set of TNMs. The set of TNMs shows an adjusted $R^{2}$ of 0.57 . However, adding elevation showed very little improvement, as the SD and elevation had a great collinearity.

\section{Discussion and Conclusions}

The temporal and spatial variability of snow density (SDEN) were studied in this paper, using the biggest SDEN data bank for on-site manual samples and automatic measurements in the Spanish Pyrenees. More than 375 manual samples and 21,000 automatic TNM data from the ERHIN program and Ebro Water Authority were used to define SDEN variability in the Spanish Pyrenees. Single and multiple linear regressions were conducted, relating SDEN with the time dependence and other drivers such as the seasonal accumulated precipitation, average temperatures, snow depth (SD) and elevation.

The automatic measurements (TNMs) provided a better description of SDEN variability than the manual SDEN sampling, as the data volume was about 20 times larger.

For both the manual samples and the TNM data, the average SDEN values and the C.V. were very similar, not following a spatial pattern. This similarity was proven as well for the set of manual samples and the set of TNM measurements. Additionally, the C.V. for the winter snow was usually larger than that of the spring snow. The Izas TNM showed similar SDEN values compared with previous works, with 0.2 and $0.3 \mathrm{~kg} / \mathrm{L}$ during the 
first months and increasing to $0.6 \mathrm{~kg} / \mathrm{L}$ at the end of the season [30]. However, it should be noted that similar values for the average and the C.V. are not representative of SDEN variability, either temporally or spatially.

Intra-annual time dependence was shown to be the predominant driver for almost all TNM sites. The densification rates ranged widely from $0.7 \times 10^{-3} \mathrm{~kg} / \mathrm{L} /$ day to $2 \times 10^{-3} \mathrm{~kg} / \mathrm{L} /$ day, without showing a spatial pattern, being $1.3 \times 10^{-3} \mathrm{~kg} / \mathrm{L} /$ day for the data from the set of TMNs. The densification rate for the set of manual samples was set to $1.2 \mathrm{~kg} / \mathrm{L} /$ day, which is very similar to the automatic measurements. The densification rates were higher than those estimated for alpine regions in the former Soviet Union and the US, with average spring SDENs $(\mathrm{kg} / \mathrm{L})$ and snow densification rates $(\mathrm{kg} / \mathrm{L} /$ day $)$ of $0.25 \mathrm{~kg} / \mathrm{L}$ and $0.79 \times 10^{-3} \mathrm{~kg} / \mathrm{L} /$ day, respectively, for the former Soviet Union and $0.31 \mathrm{~kg} / \mathrm{L}$ and $1.07 \times 10^{-3} \mathrm{~kg} / \mathrm{L} /$ day, respectively, for the US. [37].

The seasonal accumulated precipitation presented a more dominant influence than daily precipitation, being the second most dominant SDEN driver for all sites except two. Historical behaviour showed a greater influence than daily behaviour. The third most important driver was the temperature. The 7-day average temperatures showed the best fitting to SDEN. Snow densification depends on punctual temperatures for the accumulation process, but during melting cycles, average temperatures may describe it better [33]. SD was found to be less significant. For low SD, both low and high SDEN can be found, depending on an early season dominated by accumulation processes or a late season dominated by melting processes $[33,36]$. For the early season, SDEN will depend on the proportion of precipitation falling as rain and snow, so it is also possible to reach high SDEN values. However, the significance threshold of SDEN is distinctly reduced for high SD values. SDEN for the late-season snow shows higher values than the early-season snow for maximum SD as densification continues, even though the SD may keep similar values for a certain period.

The established significance order for the drivers matched with previous studies, where precipitation was the dominant climate variable at most sites, followed by the average temperature and melt-refreeze (MRF) events [37].

Multiple Linear Regression (MLR) models were created for the automatic TNM measurements and were compared with the manual samples. The predictors were added progressively from more to less dominant. Elevation was added as a predictor for the set of TMNs series, showing that the SD was enough to describe that component of SDEN variability. The adjusted $R^{2}$ ranged from 0.54 for the Bachimaña TNM to 0.83 for the Ordiceto TNM, and the set of TNMs showed an adjusted $R^{2}$ of 0.57 .

These correlation coefficients were higher than the adjusted $R^{2}$ found for single linear regressions based on its time evolution, both for the manual samples and the automatic TNM data, with the adjusted $R^{2}$ ranging from 0.27 for Eriste to 0.73 for Ordiceto and 0.44 for the set of TNMs. This greater correlation means the existence of variability in SDEN can be explained by meteorological drivers, which are highly variable in time and space.

The $R^{2}$ values are similar to those obtained in the central Spanish Pyrenees, although the scale of work was different [40], and to those for spring snow in Alpine regions of the former Soviet Union and the US $\left(R^{2}=0.68\right)$ [37]. These $R^{2}$ were obtained using MLR models with five variables (Precipitation, interactive SDmax * Temp, Cooling Degree Day, Latitude and Elevation). In the Swiss Alps, according to three elevation range classes ( $\geq 2000 \mathrm{~m}, \geq 1400$ and $<2000 \mathrm{~m},<1400 \mathrm{~m}$ ) and 12 seasonal classes (months), SDEN was fitted to the SD with the $R^{2}$ values ranging from 0.02 to a maximum of 0.58 [36].

The results presented in Table 6 show that, in order to increase the available data and reduce uncertainties to enlarge the knowledge of SDEN in the Spanish Pyrenees, further revision and calibration should be carried out on TNMs 3 (Canal Roya), 5 (Lapazosa), 10 (Airoto) and 11 (Aixeus). The last two are essential to represent spatial variability due to the Mediterranean climate. Other TNMs, such as numbers 8 (Salenques), 14 (Sarrios-Formigal) and 15 (Besurta), should enlarge their data bank to be representative and contribute to 
similar studies. Good maintenance of the meteorological network is crucial for reducing outliers, gaps or false nulls and the undervaluation of precipitation.

The validation of these SDEN regressions could be done in other Spanish mountainous areas or other regions with similar or different climates. Results regarding the eastern locations should fit better for the Atlantic Climate (the Quimboa TNM), while those regarding western locations should fit better for the Mediterranean Climate (Eriste), although no spatial patterns were observed.

The results contribute to enlarging the knowledge of SDEN in the Pyrenees and enable it to be described in a more accurate way. The SDEN regression models that are given in this work may allow us in the future to estimate SDEN, and consequently SWE, using an economical and extensive SD and meteorological network, although the high spatial variability that has been found must be taken into account. Additionally, these SDEN regression models can be implemented in hydrological snow models to describe more complex snow transport or forced-convection phenomena now that wind velocities are increasingly more available. Estimating a relationship between SDEN and several climate drivers allows for the impact of climate variability on SDEN to be taken into account.

Supplementary Materials: The following are available online at https://www.mdpi.com/article/10 $.3390 / w 13111598 / \mathrm{s} 1$.

Author Contributions: Conceptualization, E.L. and G.C.; methodology, E.L.; project administration, G.C.; software, E.L.; validation, G.C.; formal analysis, E.L.; writing-original draft preparation, E.L. and J.G.-R.; writing-review and editing, E.L. and G.C.; visualization, F.J.T.; supervision, F.J.T. All authors have read and agreed to the published version of the manuscript.

Funding: This research received no external funding.

Institutional Review Board Statement: Not applicable.

Informed Consent Statement: Not applicable.

Data Availability Statement: Data is contained within article and supplementary material.

Acknowledgments: The authors acknowledge F. Pastor and F. J. Sánchez (Spanish Ministry for Ecological Transition and the Demographic Challenge); M. L. Moreno (Ebro Water Authority); the Ebro Water Authority and field engineers A. Pedrero-Muñoz and M. Motes (SPESA Ingenieria). The authors fully acknowledge the financial support provided by the Department of Geological and Geotechnical Engineering of the UPV.

Conflicts of Interest: The authors declare no conflict of interest.

\section{References}

1. Morán-Tejeda, E.; Fassnacht, S.R.; Lorenzo-Lacruz, J.; López-Moreno, J.I.; García, C.; Alonso-González, E.; Collados-Lara, A.-J. Hydro-Meteorological characterization of major floods in Spanish mountain rivers. Water 2019, 11, 2641. [CrossRef]

2. López-Moreno, J.I.; García-Ruiz, J.M. Influence of snow accumulation and snowmelt on streamflow in the central Spanish Pyrenees/Influence de l'accumulation et de la fonte de la neige sur les écoulements dans les Pyrénées centrales espagnoles. Hydrol. Sci. J. 2004, 49. [CrossRef]

3. Morán-Tejeda, E.; Lorenzo-Lacruz, J.; López-Moreno, J.I.; Rahman, K.; Beniston, M. Streamflow timing of mountain rivers in Spain: Recent changes and future projections. J. Hydrol. 2014, 517, 1114-1127. [CrossRef]

4. Mandal, S.T.; Sharma, M.C. Spatial changes in glaciers between 1965 and 2018 in Tirungkhad Watershed, Upper Sutlej Basin, Himachal Pradesh. Earth Syst. Environ. 2020, 4, 427-438. [CrossRef]

5. Corripio, J.G.; López-Moreno, J.I. Analysis and predictability of the hydrological response of mountain catchments to heavy rain on snow events: A case study in the Spanish pyrenees. Hydrology 2017, 4, 20. [CrossRef]

6. Mellor, M. Snow and Ice on the Earth's Surface; Report II-C1; Cold Regions Research and Engineering Laboratory: Hanover, NH, USA, 1964.

7. Sommerfeld, R.A.; LaChapelle, E. The classification of snow metamorphism. J. Glaciol. 1970, 9, 3-17. [CrossRef]

8. Gartska, W.U. Snow and snow survey. In Handbook of Applied Hydrology; Chow, V.T., Ed.; McGraw-Hill: New York, NY, USA, 1964; Section 10; pp. 10-12.

9. Anderson, E.A. A Point Energy and Mass Balance Model of a Snow Cover; US Department of Commerce, National Oceanic and Atmospheric Administration, National Weather Service, Office of Hydrology: Silver Spring, MA, USA, 1976. 
10. Gray, D.M.; Male, D.H. Handbook of Snow, Principles, Processes, Management E Use; Pergamon Press, Inc.: Westchester County, NY, USA, 2004.

11. Dingman, L. Physical Hydrology, 2nd ed.; Prentice Hall: Hoboken, NJ, USA, 2002.

12. Colbeck, S.C. An overview of seasonal snow metamorphism. Rev. Geophys. Space Phys. 1982, 20, 45-61. [CrossRef]

13. Akitaya, E. Studies on depth hoar. Contrib. Inst. Low Temp. Sci. 1974, 26, 1-67.

14. Armstrong, R.L. An analysis of compressive strain in adjacent temperature-gradient and equi-temperature layers in a natural snow cover. J. Glaciol. 1980, 26, 283-289. [CrossRef]

15. Anderson, E.A. Development and testing of snow pack energy balance equations. Water Resour. Res. 1968, 4, 19-37. [CrossRef]

16. Anderson, E.A. Snow Accumulation and Ablation Model-SNOW 17; US Department of Commerce, National Oceanic and Atmospheric Administration, National Weather Service, National Weather Service River Forecast System: Newburyport, MA, USA, 2006; p. 61.

17. Lantarón, J.H. Modelo Físico de Acumulación y Fusión de la Nieve. Aplicación en Sierra Nevada (España). Ph.D Thesis, University of Granada, Granada, Spain, November 2007.

18. Brun, E. Investigation on wet-snow metamorphism in respect of liquid-water content. Ann. Glaciol. 1989, 13, 22-26. [CrossRef]

19. Bilello, M.A. Regional and Seasonal Variations in Snow-Cover Density in the U.S.S.R. [Microform]/Michael A. Bilello (No. CRREL Report RR 84-22); US Army Corps of Engineers, Cold Regions Research \& Engineering Laboratory: Washington, DC, USA, 1984.

20. Onuchin, A.A.; Burenina, T.A. Climatic and geographic patterns in snow density dynamics. North. Eurasia. Arct. Alp. Res. 1996, 28, 99-103. [CrossRef]

21. Sturm, M.; Holmgren, J. Differences in compaction behavior of three climate classes of snow. Ann. Glaciol. 1998, 26, 125-130. [CrossRef]

22. Kershaw, G.P.; McCulloch, J. Midwinter snowpack variation across the Arctic treeline, Churchill, Manitoba, Canada. Arct. Antarct. Alp. Res. 2007, 39, 9-15. [CrossRef]

23. Meløysund, V.; Leira, B.; Høiseth, K.V.; Lisø, K.R. Predicting snow density using meteorological data. Meteorol. Appl. 2007, 14, 413-423. [CrossRef]

24. Paquet, E.; Laval, M.; Basalaev, L.M.; Belov, A.; Eroshenko, E.; Kartyshov, V.; Struminsky, A.; Yanke, V.L. An application of cosmic-ray neutron measurements to the determination of the snow water equivalent. In Proceedings of the 30th International Cosmic Ray Conference, Merida, Mexico, 3-11 July 2007; Universidad Nacional Autónoma de México: Mexico City, Mexico, 2008.

25. Kodama, M.; Nakai, K.; Kawasaki, S.; Wada, M. An application of cosmic-ray neutron measurements to the determination of the snow-water equivalent. J. Hydrol. 1979, 41, 85-92. [CrossRef]

26. Kinar, N.J.; Pomeroy, J.W. Automated determination of snow water equivalent by acoustic reflectometry. IEEE Trans. Geosci. Remote Sens. 2009, 47, 3161-3167. [CrossRef]

27. Alonso, R.; del Pozo, J.M.G.; Buisán, S.T.; Álvarez, J.A. Analysis of the snow water equivalent at the AEMet-formigal field laboratory (Spanish Pyrenees) during the 2019/2020 winter season using a stepped-frequency continuous wave radar (SFCW). Remote Sens. 2021, 13, 616. [CrossRef]

28. Collados-Lara, A.J.; Pulido-Velázquez, D.; Pardo-Igúzquiza, E.; Alonso-González, E. Estimation of the spatiotemporal dynamic of snow water equivalent at mountain range scale under data scarcity. Sci. Total Environ. 2020, 41, 140485. [CrossRef]

29. López-Moreno, J.I.; Nogués-Bravo, D. Interpolating local snow depth data: An evaluation of methods. Hydrol. Process. 2006, 20, 2217-2232. [CrossRef]

30. López Moreno, J.I.; Quirós, B.A.; Latron, J.; Fassnacht, S.R. Instalación y uso de un colchón de nieve para la monitorización del manto de nieve, cuenca experimental de Izas (Pirineo Central). Geogr. Res. Lett. 2010, 36, 73-82. [CrossRef]

31. Anderton, S.P.; White, S.M.; Alvera, B. Evaluation of spatial variability in snow water equivalent for a high mountain catchment. Hydrol. Process. 2004, 18, 435-453. [CrossRef]

32. Elder, K.; Dozier, J.; Michaelsen, J. Snow accumulation and distribution in an Alpine watershed. Water Resour. Res. 1991, 27, 1541-1552. [CrossRef]

33. Mizukami, N.; Perica, S. Spatiotemporal characteristics of snowpack density in the mountainous regions of the western United States. J. Hydrometeorol. 2008, 9, 1416-1426. [CrossRef]

34. Rohrer, M.; Braun, L.N.; Lang, H. Long-term records of snow cover water equivalent in the Swiss Alps: 1. analysis. Nord. Hydrol. 1994, 25, 53-64. [CrossRef]

35. Brown, R.D. Northern Hemisphere snow cover variability and change, 1915-1997. J. Clim. 2000, 13, 2339-2355. [CrossRef]

36. Jonas, T. Estimating the snow water equivalent from snow depth measurements in the Swiss Alps. J. Hydrol. 2009, 378, 161-167. [CrossRef]

37. Bormann, K.J.; Westra, S.; Evans, J.P.; McCabe, M.F. Spatial and temporal variability in seasonal snow density. J. Hydrol. 2013, 484, 63-73. [CrossRef]

38. Alonso-González, E.; López-Moreno, J.I.; Gascoin, S.; García-Valdecasas Ojeda, M.; Sanmiguel-Vallelado, A.; Navarro-Serrano, F.; Revuelto, J.; Ceballos, A.; Esteban Parra, M.J.; Essery, R. Daily gridded datasets of snow depth and snow water equivalent for the Iberian Peninsula from 1980 to 2014. Earth Syst. Sci. Data 2018, 10, 303-315. [CrossRef]

39. Essery, R. A factorial snowpack model (FSM 1.0). Geosci. Model Dev. 2015, 8, 3867-3876. [CrossRef] 
40. López-Moreno, J.I.; Fassnacht, S.R.; Heath, J.T.; Musselman, K.N.; Revuelto, J.; Latron, J.; Morán-Tejeda, E.; Jonas, T. Small scale spatial variability of snow density and depth over complex alpine terrain: Implications for estimating snow water equivalent. Adv. Water Resour. 2013, 55, 40-52. [CrossRef]

41. Navarro-Serrano, F.M.; López-Moreno, J.I. Spatio-temporal analysis of snowfall events in the Spanish Pyrenees and their relationship to atmospheric circulation. Geogr. Res. Lett. 2007, 43, 233-254.

42. Cobos, G.; Frances, M.; Arenillas, M. Le programme ERHIN. Modélisation nivo-hydrologique pour la gestion de l'eau du Bassin De l'Ebre. The ERHIN programme. Hydrological-nival modelling for the management of water resources in the Ebro Basin. La Houille Blanche 2010, 3, 58-64. [CrossRef]

43. Serreze, M.C.; Clark, M.P.; Armstrong, R.L.; McGinnis, D.A.; Pulwarty, R.S. Characteristics of the western United States snowpack telemetry (SNOTEL) data. Water Resour. Res. 1999, 35, 2145-2160. [CrossRef]

44. Arenillas, M.; Cobos, G.; Navarro, J. Datos sobre la nieve y los glaciares en las cordilleras españolas. In El Programa ERHIN (1984 a 2008); Ministerio de Obras Públicas y Transporte-MOPT: Madrid, Spain, 2008.

45. Dixon, D.; Boon, S. Comparison of the SnowHydro snow sampler with existing snow tube designs. Hydrol. Process. 2012, 26, 2555-2562. [CrossRef]

46. World Meteorological Organization. Guide to Instruments and Methods of Observation. Volume II: Measurement of Cryospheric Variables, 2018 ed.; WMO: Geneva, Switzerland, 2018.

47. Farnes, P.F.; Goodison, B.E.; Peterson, N.R.; Richards, R.P. Metrication of manual snow sampling equipment. In Proceedings of the 50th Annual Meeting, Western Snow Conference, Reno, NV, USA, 19-23 April 1982.

48. López-Moreno, J.I.; Leppänen, L.; Luks, B.; Holko, L.; Picard, G.; Sanmiguel-Vallelado, A.; Alonso-González, E.; Finger, D.C.; Arslan, A.N.; Gillemot, K.; et al. Intercomparison of measurements of bulk snow density and water equivalent of snow cover with snow core samplers: Instrumental bias and variability induced by observers. Hydrol. Process. 2020, 34, 3120-3133. [CrossRef] 